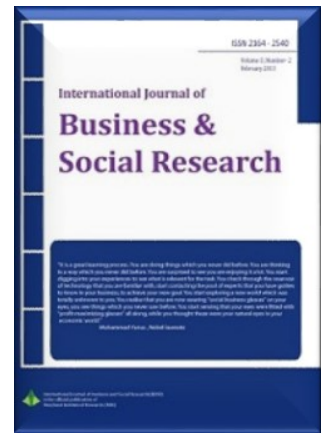

\title{
Extrinsic and Intrinsic Factors Influencing Employee Motivation: Lessons from AMREF Health Africa in Kenya
}

\author{
Stephen Morangi Nyambegera', Caroline Njambi Gicheru²
}

\begin{abstract}
The purpose of the study was to determine the factors that influence employee motivation in Kenyan Organizations. The study was guided by the following research questions: (i) what are the extrinsic factors that influence employee motivation in AMREF Health Africa in Kenya? (ii) what intrinsic factors influence employee motivation in AMREF Health Africa in Kenya? A descriptive research design was adopted. Stratified random sampling technique was used to draw a sample size of 96 respondents. The data collection instrument was a structured questionnaire developed by the researchers. A set of descriptive and correlation statistics were adopted for analysis. The study identified several intrinsic factors that influence employee motivation. These included employee achievements, recognition, work itself, responsibility and advancement, salary structure, the level to which the employees feel appreciated, and the employee perception of their jobs among other factors. The study further, established that the intrinsic factors that influence employee motivation include empowerment and autonomy, employees' view of their work, organization trust, skill variety requirements among others. The study recommends that the organization should acknowledge and make use of a proper mix of extrinsic and intrinsic factors in their human resource management practices to ensure that employees are well motivated to perform their tasks.
\end{abstract}

Keywords: Employee motivation, health care.

Available Online: 12-10-2016

This is an open access article under Creative Commons Attribution 4.0 License, 2016.

\section{0}

\section{INTRODUCTION}

Mudor and Tookson (2011) contend that every organization desires to be successful as much as the current environment is very competitive. Organizations irrespective of size and market strive to retain the best employees, acknowledging their important role and influence on organizational effectiveness (Armstrong, 2011). In order to overcome challenges, organizations should create a strong and positive relationship with its employees, direct them towards task fulfilment and ensure they have job satisfaction (Fisher, 2012). In order to achieve their goals and objectives, organizations develop strategies to compete in highly competitive markets and to increase their performance. Nevertheless, just a few organizations consider human capital as being their main asset, capable of leading them to success or if not managed

\footnotetext{
${ }^{1}$ United States International University. E-mail: snyambegera@yahoo.co.uk

${ }^{2}$ Amref Health Africa in Kenya, Programs Administrator. E-mail: cnjambi@amref.org
} 
properly can lead to failure of the organization and high staff turnover (Fisher, 2012).

According to Ran (2009), employers are faced with the task of motivating employees and creating high job satisfaction among their staff. Developing programs and policies that embrace job satisfaction and serve to motivate employees takes time and money. When the employer understands the benefits of motivation in the workplace, then the investment in employee-related policies can be easily justified. If the employees are not satisfied with their jobs and not motivated to fulfil their tasks and achieve their goals, the organization cannot attain success. People have different needs that are continuously competing with each other and vary with an individual. Each person has a different mixture and strength of needs, as some people are driven by achievement while others are focusing on security. If the managers are able to understand, predict and control employee behaviour, they should also know what employees want from their jobs. For that reason, it is essential for a manager to understand what really motivates employees without making assumptions (Gurland and Lam, 2008).

Motivation as stated by Ran (2009) is generally defined as the process that accounts for an individual's intensity, direction, and persistence of effort toward attaining a goal. It was also described by Elliot and Zahn (2008) as the strength and course of behaviour. In certain instances, motivation can serve as the explanation and the prediction of behaviour of a particular individual's work performance. Motivation refers to the reasons underlying behaviour (Guay, 2010). Intrinsic motivation is motivation that is animated by personal enjoyment, interest, or pleasure. Intrinsic motivation energizes and sustains activities through the spontaneous satisfactions inherent in effective volitional action. It is manifested in behaviours such as play, exploration, and challenge that people often do seek for external rewards. Researchers often contrast intrinsic motivation with extrinsic motivation, which is motivation governed by reinforcement contingencies from within the individual (Irons and Buskist, 2008).

\subsection{BACKGROUND OF THE STUDY}

Customarily, educators consider intrinsic motivation to be more desirable and to result in better learning outcomes than extrinsic motivation (Irons and Buskist, 2008). In comparison to financial resources, human resources have the capability to create competitive advantage for their organizations. Normally, employee performance depends on a large number of factors, such as motivation, appraisals, job satisfaction, training and development and so forth, however this paper focuses only on employee motivation, as it has been shown to influence to a significant degree the organizational performance. In addition it has been claimed that motivated employees tend to have better mental and physical health and learn new job related tasks more quickly. All these considered by practicing managers and organizational behaviour researchers, they would agree that employee motivation is important to an organization. Critics however, point out these are pure assumptions because there is so much we do not know about the positive effects of motivation. On the other hand, when employee motivation is low, there seems to be negative effects on the organization that have been documented. So if only from the standpoint of viewing employee motivation as a minimum requirement or point of departure, it is of value to the organization's overall health and effectiveness and is deserving of study and application in the long term. Getting employees to reach their full potential at work under stressful conditions is a tough challenge, but this can be achieved by motivating them (Santrock, 2009).

Motivator factors are factors that are intrinsic to the job, such as the content of the work itself and the availability of opportunities for responsibility, advancement and recognition for achievement (Santrock, 2009). Hygiene factors are extrinsic to the job and relate to the environment in which the job is performed. Such factors include the organization's policy and administration, working conditions, salary, supervision and interpersonal relations. Herzberg argued that the extrinsic aspects of work (the hygiene factors) could not provide a source of motivation for employees but could, if 'bad', provide a source of dissatisfaction and thus demoralize employees. Hygiene factors should be seen as the prerequisite to allow the motivating factors to influence employee's motivation. In a situation where there were 'good' hygiene factors, the employee would be in a state of 'no dissatisfaction'. The motivator factors, which Herzberg (1959) described as complex factors leading to this sense of personal growth and self- 
actualization, would then reflect employee motivation hence increase job satisfaction and productivity. As a consequence, in order to motivate workers towards higher productivity, while it is important to ensure that the hygiene factors are correct, the manager must manipulate the motivators by attending to job-content issues for example job-enrichment (Sisk, 2009).

Even though a lot has been written on motivation, this subject is not clearly understood and more often than not poorly practiced. To well comprehend how motivation can impact on employee's performance, one must identify with human nature. In as much as motivation impacts on employee performance, there is need to blend the appropriate motivational tools with effective management and leadership to achieve this goal. Even though the fact that motivation is very important to determine employee's ability, so are other factors such as the resources given to an employee to perform his or her job. For this reason, successful work performance can arise from a variety of motives. For instance, one salesperson may be motivated by the commission earned on sales, while the other may be more concerned about achieving sales targets. This creates a fine distinction in the subject matter because motivation to enhance performance varies from person to person and from organization to organization (Daft, 2009).

AMREF Health Africa in Kenya was officially founded in 1957 to deliver mobile health services and to provide mission hospitals with surgical support. A medical radio network was developed to coordinate the service, and provide communication. In the early 1960s, ground-based mobile medical services were added, along with 'flight clinics' for the under-served and remote areas in Kajiado and Narok districts of Kenya. In 1975, training and education for rural health workers were already a major part of AMREF Health Africa in Kenya's efforts including the development of health learning materials. By late 1970s, AMREF Health Africa in Kenya continued providing mobile clinical and maternal child/health (MCH) services. It also started to focus on community-based health care ( $\mathrm{CBHC}$ ) and training community health workers to deliver primary health care as well as technical support units for $\mathrm{CBHC}, \mathrm{MCH}$, family planning and environmental health (AMREF, 2014). During the 1980s, AMREF Health Africa in Kenya moved into community health development, closer collaboration with the ministry of health in the region, and cooperation with international aid agencies. This set the organization's course for the 1980 s and beyond. Greater emphasis was given to strengthening health systems and staff development, with special attention to health needs identified by communities themselves. AMREF Health Africa in Kenya staff gained experience in planning and the management of health services at a national level - expertise that has since been shared in-house with health ministries (the first was Uganda), (AMREF, 2014).

In the early 1990s AMREF Health Africa in Kenya established a unique year-long training course in community health. The 1990 s also saw AMREF Health Africa in Kenya's work expand to include disease control initiatives, focusing on malaria, HIV/AIDS and TB. At some stage in the mid-1990s, AMREF Health Africa in Kenya increased its focus on HIV/AIDS as it looked set to undo much of the progress made in health during the 2oth century, and become a major burden to health systems in poor countries. In recent years, AMREF Health Africa in Kenya has highlighted the fact that despite huge investments by donors in health products and delivery of health services, a large percentage of Africans still have limited access to sufficient and quality health care. The organization has a very diverse workforce and views employee motivation as very critical in order to attain maximum performance. It is therefore this organization that the study was focused on in order to determine what factors motivate employees (AMREF, 2014).

\subsection{STATEMENT OF THE PROBLEM}

Employee motivation is a topic that has received significant attention by practitioners and researchers alike (Gautam, Mandal and Dalal, 2006). Studies have established that high labour turnover and absenteeism is due to poor working conditions, long hours and low pay which are among employee demotivators (Cheng, 1995). Cheng further notes that managers have realised that it is difficult to motivate employees due to the fact that motivators can shift depending on circumstances. Even if this is the case 
managers still aim to motivate their employees so that they not only enhance their performance and job satisfaction but also through satisfaction enhance their retention rate (Chianga and Jang, 2008). It is acknowledged with certainty that no organization can possibly thrive without their employees. Employees are an important asset that can sustain organization performance for a long time. Similarly at AMREF Health Africa in Kenya, employees are the ones who play major roles and make significant contributions to the organization. Well motivated employees would influence the efficiency of the organization and could lead to achieving the organization's vision and goals (Hussin, 2011).

Studies on employee motivation have been carried out over the years but they are largely based on western organizations models (e.g., Grant, Fried, and Juillerat, 2010) and very few studies on motivation have been done in African organizations particularly in Kenya and non in AMREF Health Africa. Other studies have documented that different socio-economic groups appear to attach different meanings to, or have different orientations towards work. Different groups of individuals may have different attitudes and opinions towards the same. They are also likely to react differently towards management policies (Latham and Locke, 2007). At the same time as well-meaning human relations policies on the part of management may appeal to certain groups of workers. A model of worker motivation should therefore be able to differentiate between different types of worker and treat the wants, expectations and attitudes towards work as culturally determined variables, not psychological constants (Irons and Buskist, 2008). It is arguable then that employees in different environments affiliated to different cultures cannot attain motivation from universal factors (Nyambegera, et al., 2000). Other studies focus on only extrinsic factors like pay, promotion and working condition (e.g., Karatepe and Uludag, 2007). From the above one can see a clear research gap that needs to be filled an endeavour this study aims to make a contribution.

There has been a great challenge on the part of managers in AMREF Health Africa in Kenya on determining how exactly they can attain maximum motivation for their employees whom they believe would go a long way to improve organizational performance (AMREF, 2014). Many managers have tried to attain motivation of their employees by using methods that were successful in other contexts around the world and have been disappointed because these studies were not directly relevant to employees everywhere. It is for this and other reasons presented earlier in this paper that this research was intended to establish the extrinsic and intrinsic factors that motivate employees in AMREF Health Africa in Kenya to provide lessons to similar organizations in the region. The following research questions guided this study:

Research Question 1: What intrinsic factors influence employee motivation at AMREF Health Africa in Kenya?

Research Question 2: What extrinsic factors influence employee motivation at AMREF Health Africa in Kenya?

\subsection{METHODOLOGY}

The research design that was used for the study was a descriptive in nature. A descriptive design collects data in order to answer questions about current status of the subject or topic of study. The researchers believed that a descriptive research design was appropriate for this study because this study was concerned with finding out what the factors are, that influence motivation of employees. The study population comprised a total of 412 employees of AMREF Health Africa in Kenya from various organizational departments. Using stratified sampling technique a sample size of 96 respondents was chosen. A structured questionnaire piloted with 10 respondents that were not used in the study proper and Cronbach Alpha method of internal consistency was used to compute the reliability of the measures of the variables of the study and validity was tested by the use of experts in the field. Descriptive analysis was used to determine the proportions and frequency of the variables while correlation analysis was used to draw inferences about the population from the organization. 


\subsection{RESULTS}

\subsection{RESPONSE RATE AND RESPONDENTS' PROFILE}

A sample size of 96 respondents with 96 questionnaires administered, all were returned dully completed giving a response rate of $100 \%$ which was as a result of close follow up of the respondents. Table 1 reports results of respondents' profile showing that eleven respondents (12\%) were aged below 25 years while 53 respondents (55\%) were aged between 25 and 34 years. Twenty-two respondents (23\%) indicated that they aged between 35 and 44 years while the rest of ten (10\%) respondents were aged above 45 years. Sixty per cent $(60 \%)$ of the respondents indicated that they were male. The rest of the respondents, making up 40\% were female showing that majority of employees are male. From the study it was found that $32 \%$ of the respondents possessed an undergraduate degree. Twenty-six per cent of the respondents held a MBA degree while $25 \%$ held other graduate degrees. Ten per cent (10\%) of the respondents indicated that they had a post-graduate degree while the rest, comprising of $6 \%$ of the respondents possessed other professional qualifications. The study also wanted to know the department respondents belonged to and $88 \%$ belonged to the programs department, $7 \%$ were in the administrations and procurement department while the rest, $5 \%$ belonged to the finance department. Finally, the other issue under respondents' profile was the length of service with the organization and from Table 1 it is observed that $4 \%$ had worked in the organization for more than ten years, 31\% for between 5 and 9 years and the majority $65 \%$ reported that they had worked in the organization for 4 years and below.

\begin{tabular}{lr}
\hline & Table 1: Respondents' profile \\
\hline Age & Percentage \\
$<25$ & $12 \%$ \\
$25-34$ & $55 \%$ \\
$35-44$ & $23 \%$ \\
$>45$ & $10 \%$ \\
\hline Gender & Percentage \\
Male & $60 \%$ \\
Female & $40 \%$ \\
\hline Education Background & Percentage \\
Undergraduate & $32 \%$ \\
Graduate (MBA) & $26 \%$ \\
Graduate (Other) & $25 \%$ \\
Postgraduate & $10 \%$ \\
Professional Qualifications & $6 \%$ \\
\hline Department & Percentage \\
Programs & $88 \%$ \\
Administration and Procurement & $7 \%$ \\
Finance & $5 \%$ \\
\hline Length of Service & Percentage \\
O-4 Years & $65 \%$ \\
$5-9$ Years & $31 \%$ \\
$>10$ Years & $4 \%$ \\
\hline &
\end{tabular}

\subsection{DESCRIPTIVE STATISTICS ON EXTRINSIC FACTORS THAT INFLUENCE EMPLOYEE MOTIVATION}

Table 2 reports descriptive results in form of percentages for extrinsic factors influencing employee motivation at AMREF Health Africa in Kenya. Majority of respondents 31\% agree and $43 \%$ strongly agree, while $6 \%$ either disagree or disagree and $20 \%$ are neutral. This is expected in a country were most employees are still trying to meet the basic needs according to Maslow's hierarchy of needs. The other extrinsic factor assessed in this study was leadership style. Again, 51\% and 39\% agree and strongly agree 
respectively that leadership style is a major influencer of employee motivation. Thirty-eighty respondents (39\%) strongly agreed and 43 respondents (45\%) agreed that they strongly agreed and agreed respectively that job enrichment influences motivation while the rest either strongly disagreed or disagreed. On whether management of information within the organization influenced employee motivation, 68\% agreed and $20 \%$ strongly agreed supported the fact that information management influences employee motivation. Quality of work environment was one of the other issues investigated in this study and the results indicate that a majority $62 \%$ agreed while $22 \%$ strongly agreed that quality of the work environment does influence employee motivation. The researchers also sought to know whether effective dissemination of information within the organization influenced employee level of motivation. Sixty eight per cent of the respondents and $20 \%$ indicated that they agreed and strongly agreed respectively that effective dissemination of information within the organization influenced their level of motivation. Forty-one respondents (43\%) and 37 respondents (39\%) indicated that they agreed and strongly agreed respectively that employee-management relationship influenced employee motivation. It was interesting to note that some respondents do not think that availability of promotion opportunities influences their motivation although in the minority at $8 \%$ disagreed and $25 \%$ were noncommittal. On the contrary, $17 \%$ and $50 \%$ of the respondents making $67 \%$ indicated that they agreed and strongly agreed respectively that the availability of promotion opportunities within the organization influenced the level of their motivation as employees. Some non-financial extrinsic factors like congenial co-workers influenced employee motivation $18 \%$ indicated that they strongly agreed while $47 \%$ indicated that they agreed that congenial co-workers influenced the level of motivation while $25 \%$ were neutral. The last issue investigated was whether the nature of jobs influenced employee motivation. Fifty-nine $p$ er cent (59\%) and $22 \%$ of the respondents agreed and strongly agreed respectively that employee motiva tion influenced employee motivation.

Table 2: Extrinsic factors that influence employee motivation

\begin{tabular}{|c|c|c|c|c|c|}
\hline Statement/Variable & $\begin{array}{l}\text { Strongly } \\
\text { Disagree }\end{array}$ & Disagree & $\begin{array}{r}\text { Neither Agree } \\
\text { or Disagree }\end{array}$ & Agree & $\begin{array}{r}\text { Strongly } \\
\text { Agree }\end{array}$ \\
\hline $\begin{array}{l}\text { Monetary compensation/salary structure } \\
\text { influence motivation }\end{array}$ & $4 \%$ & $2 \%$ & $20 \%$ & $31 \%$ & $43 \%$ \\
\hline $\begin{array}{l}\text { The Leadership Style Influences Employee } \\
\text { Motivation }\end{array}$ & $4 \%$ & $6 \%$ & $0 \%$ & $51 \%$ & $39 \%$ \\
\hline $\begin{array}{l}\text { Job enrichment by the organization } \\
\text { influences motivation }\end{array}$ & $2 \%$ & $2 \%$ & $13 \%$ & $45 \%$ & $39 \%$ \\
\hline $\begin{array}{l}\text { Organizational information management } \\
\text { influences motivation }\end{array}$ & $2 \%$ & $0 \%$ & $10 \%$ & $68 \%$ & $20 \%$ \\
\hline $\begin{array}{l}\text { Quality of the work environment } \\
\text { influences motivation }\end{array}$ & $0 \%$ & $2 \%$ & $15 \%$ & $62 \%$ & $22 \%$ \\
\hline $\begin{array}{l}\text { Effective dissemination of information } \\
\text { influences motivation }\end{array}$ & $2 \%$ & $0 \%$ & $10 \%$ & $68 \%$ & $68 \%$ \\
\hline $\begin{array}{l}\text { Employee-management } \quad \text { relationship } \\
\text { influences motivation }\end{array}$ & $4 \%$ & $2 \%$ & $16 \%$ & $43 \%$ & $39 \%$ \\
\hline $\begin{array}{l}\text { Availability of promotion opportunities } \\
\text { influences employee motivation }\end{array}$ & $0 \%$ & $8 \%$ & $25 \%$ & $17 \%$ & $50 \%$ \\
\hline $\begin{array}{l}\text { Congenial co-workers influence employee } \\
\text { motivation }\end{array}$ & $0 \%$ & $10 \%$ & $25 \%$ & $47 \%$ & $18 \%$ \\
\hline $\begin{array}{l}\text { The Nature of Job influences employee } \\
\text { motivation }\end{array}$ & $4 \%$ & $0 \%$ & $15 \%$ & $59 \%$ & $22 \%$ \\
\hline
\end{tabular}

\subsection{DESCRIPTIVE STATISTICS FOR INTRINSIC FACTORS INFLUENCE ON EMPLOYEE MOTIVATION}

Table 3 shows results of descriptive statistics of intrinsic factors influence on employee motivation. Six per cent of respondents (6\%) indicated that they strongly disagreed that the appreciation of employees 
by the organization had an effect on motivation, whereas $25 \%$ and $53 \%$ agreed and strongly agreed respectively that appreciation of employees does influence motivation. The second item that the researchers were interested in is whether skill variety requirements influenced motivation. Majority of the respondents answered to the affirmative since $70 \%$ agreed and $6 \%$ strongly agreed that skill variety requirements do influence motivation. On whether the way employees perceived their jobs as influencing motivation, a majority $54 \%$ agreed and $20 \%$ strongly agreed totalling $74 \%$ of those agreeing. The rest were either neutral or disagreed. The researchers also investigated whether the degree of trust exhibited at the workplace influences their motivation.

Twenty one per cent (21\%) of the respondents were neutral, whereas the majority $54 \%$ agreed and $16 \%$ strongly agreed. The other intrinsic factor investigated was whether constant feedback regarding employee performance influences motivation. Thirty one per cent (31\%) of the respondents agreed and $28 \%$ strongly agreed that constant feedback regarding employee performance influences motivation. Employee responsibility is another type of intrinsic factor that influences employee motivation where $41 \%$ of the respondents agreed and $20 \%$ strongly agreed while the rest either disagreed or were noncommittal.

Thirty respondents (31\%) and 48 respondents (50\%) indicated that they agreed and strongly disagreed respectively that the level of fairness in treatment of employees influences job motivation. Employee perception regarding skill development does influence motivation as $40 \%$ indicated that they agreed while $32 \%$ strongly agreed and a minority disagreed or were neutral. Thirty-three respondents (34\%) and 45 respondents (47\%) indicated that they strongly agreed and agreed respectively that they got motivated whenever they felt that they contributed to the growth of the organization.

The last item that was investigated is employee empowerment and autonomy's influence on motivation. Four per cent of the respondents disagreed and 6\% strongly disagreed that the level of employee empowerment and autonomy influenced motivation. Nineteen per cent (19\%) were neutral while the majority $41 \%$ agreed and $24 \%$ strongly agreed that the level of employee empowerment and autonomy influenced motivation.

\begin{tabular}{|c|c|c|c|c|c|}
\hline \multicolumn{6}{|c|}{ Table 3: Intrinsic factors that influence employee motivation } \\
\hline Statement/Variable & $\begin{array}{l}\text { Strongly } \\
\text { Disagree }\end{array}$ & Disagree & $\begin{array}{r}\text { Neither Agree } \\
\text { or Disagree }\end{array}$ & Agree & $\begin{array}{r}\text { Strongly } \\
\text { Agree }\end{array}$ \\
\hline $\begin{array}{l}\text { Appreciation by the organization } \\
\text { influences motivation }\end{array}$ & $6 \%$ & $0 \%$ & $15 \%$ & $25 \%$ & $53 \%$ \\
\hline $\begin{array}{l}\text { Skill variety requirements influence } \\
\text { motivation }\end{array}$ & $2 \%$ & $7 \%$ & $15 \%$ & $70 \%$ & $6 \%$ \\
\hline $\begin{array}{l}\text { Employee view of the job influences } \\
\text { motivation }\end{array}$ & $2 \%$ & $5 \%$ & $19 \%$ & $54 \%$ & $20 \%$ \\
\hline Organization trust influences motivation & $2 \%$ & $7 \%$ & $21 \%$ & $54 \%$ & $16 \%$ \\
\hline $\begin{array}{l}\text { Feedback on employee performance } \\
\text { influences motivation }\end{array}$ & $16 \%$ & $0 \%$ & $24 \%$ & $31 \%$ & $28 \%$ \\
\hline $\begin{array}{l}\text { Employee responsibilities impact on } \\
\text { overall motivation }\end{array}$ & $4 \%$ & $8 \%$ & $27 \%$ & $41 \%$ & $20 \%$ \\
\hline $\begin{array}{l}\text { Fairness in treatment of employees } \\
\text { influences motivation }\end{array}$ & $6 \%$ & & $13 \%$ & $31 \%$ & $50 \%$ \\
\hline $\begin{array}{l}\text { Employee perception on skill } \\
\text { development influences motivation }\end{array}$ & $0 \%$ & $7 \%$ & $21 \%$ & $40 \%$ & $32 \%$ \\
\hline $\begin{array}{l}\text { Perception about contributing to firm's } \\
\text { growth influences motivation }\end{array}$ & $6 \%$ & $4 \%$ & $8 \%$ & $47 \%$ & $34 \%$ \\
\hline $\begin{array}{l}\text { Employee empowerment and autonomy } \\
\text { influence motivation }\end{array}$ & $4 \%$ & $6 \%$ & $19 \%$ & $47 \%$ & $24 \%$ \\
\hline
\end{tabular}




\subsection{CORRELATION ANALYSIS RESULTS}

\subsubsection{CORRELATION OF EXTRINSIC FACTORS ON EMPLOYEE MOTIVATION}

The correlation results in Table 4 are taken against a more conservative significance level of $p<0.05$ to minimize the possibility of type 1 error (Hays, 1988). Job enrichment and working environment stand out as having the strongest relationship with employee motivation.

Overall, employee motivation is associated with eight out of the nine extrinsic factors of motivation, as can be seen from Table 4. Results also indicate rather intriguingly, that congenial co-workers have no significant association with employee motivation because Kenya being a group oriented society social needs tend to be rather important.

Table 4: Correlation of extrinsic factors and employee motivation

\begin{tabular}{|c|c|c|c|c|c|c|c|c|c|c|}
\hline Extrinsic factors & 1 & 2 & 3 & 4 & 5 & 6 & 7 & 8 & 9 & 10 \\
\hline $\begin{array}{l}\text { Employee } \\
\text { motivation }\end{array}$ & 1.000 & & & & & & & & & \\
\hline $\begin{array}{l}\text { Monetary } \\
\text { compensation }\end{array}$ & $0.212^{*}$ & 1.000 & & & & & & & & \\
\hline Leadership Style & $0.391^{* *}$ & $.609^{* *}$ & 1.000 & & & & & & & \\
\hline Job enrichment & $0.638^{* *}$ & $.346^{* *}$ & $.501^{* *}$ & 1.000 & & & & & & \\
\hline $\begin{array}{l}\text { Information } \\
\text { effectiveness }\end{array}$ & $0.348^{* *}$ & $.299^{* *}$ & $.259^{*}$ & $.489^{* *}$ & 1.000 & & & & & \\
\hline $\begin{array}{l}\text { Working } \\
\text { environment }\end{array}$ & $0.508^{* *}$ & .162 & $.342^{* *}$ & $.798^{* *}$ & $.332^{* *}$ & 1.000 & & & & \\
\hline $\begin{array}{l}\text { Employee } \\
\text { management } \\
\text { relationship }\end{array}$ & $0.429^{* *}$ & $.414^{* *}$ & $.243^{*}$ & .191 & .193 & $\cdot 361^{* *}$ & 1.000 & & & \\
\hline $\begin{array}{l}\text { Promotion } \\
\text { opportunities }\end{array}$ & $0.250^{*}$ & $.517^{* *}$ & $.379^{* *}$ & $.297^{* *}$ & $.327^{* *}$ & $.282^{* *}$ & $.535^{* *}$ & 1.000 & & \\
\hline $\begin{array}{l}\text { Congenial co- } \\
\text { workers }\end{array}$ & 0.132 & -.015 & .045 & $.291^{* *}$ & $.440^{* *}$ & $.282^{* *}$ & $.213^{*}$ & $.543^{* *}$ & 1.000 & \\
\hline Nature of job & $0.355^{* *}$ & .155 & .123 & -.003 & .159 & $.311^{* *}$ & $.687^{* *}$ & $.414^{* *}$ & 133. & 1.000 \\
\hline
\end{tabular}

\subsubsection{CORRELATION OF INTRINSIC FACTORS ON EMPLOYEE MOTIVATION}

Table 5 reports correlation results for intrinsic factors influence on employee motivation. Organization trust for its employees; employees' view of their work; and skill variety requirements stand out as having the strongest relationship with employee motivation among the intrinsic factors as can be seen from Table 5.

Overall, nine out of the ten intrinsic factors investigated are significantly associated with employee motivation. The only intrinsic factor that has no significant association with employee motivation is perception about the importance of contributing to firm's growth.

This might be explained by the fact that employees do not feel that ownership of the organization hence valuing more their own goals. 
Table 5: Correlation between intrinsic factors and employee motivation

\begin{tabular}{|c|c|c|c|c|c|c|c|c|c|c|c|}
\hline Intrinsic factors & 1 & 2 & 3 & 4 & 5 & 5 & 6 & 7 & 8 & 9 & 10 \\
\hline $\begin{array}{l}\text { Employee } \\
\text { motivation }\end{array}$ & 1.000 & & & & & & & & & & \\
\hline $\begin{array}{l}\text { Recognition and } \\
\text { appreciation }\end{array}$ & $0.501^{* *}$ & 1.000 & & & & & & & & & \\
\hline Skill variety & $0.616^{* *}$ & $0.215^{*}$ & 1.000 & & & & & & & & \\
\hline $\begin{array}{l}\text { Work } \\
\text { meaningfulness }\end{array}$ & $0.632^{* *}$ & 0.196 & $0.766^{* *}$ & 1.000 & & & & & & & \\
\hline Trust & $0.704^{* *}$ & $0.366^{* *}$ & $0.529^{* *}$ & $0.667^{* *}$ & 1.000 & & & & & & \\
\hline Feedback & $0.580^{* *}$ & $0.205^{*}$ & $0.390^{* *}$ & $0.332^{* *}$ & $0.592^{* *}$ & 1.000 & & & & & \\
\hline $\begin{array}{l}\text { Amount of } \\
\text { responsibility }\end{array}$ & $0.424^{* *}$ & $0.334^{* *}$ & $0.207^{*}$ & $0.252^{*}$ & $0.392^{* *}$ & $0.620^{* *}$ & 1.000 & & & & \\
\hline $\begin{array}{l}\text { Fairness of } \\
\text { treatment }\end{array}$ & $0.276^{* *}$ & $0.668^{* *}$ & 0.141 & 0.065 & $0.239^{*}$ & $0.300^{* *}$ & $0.661^{* *}$ & 1.000 & & & \\
\hline $\begin{array}{l}\text { Perception of skill } \\
\text { development }\end{array}$ & $0.444^{* *}$ & $0.478^{* *}$ & $0.550^{* *}$ & $0.615^{* *}$ & $0.629^{* *}$ & $0.400^{* *}$ & $0.336^{* *}$ & $0.359^{* *}$ & 1.000 & & \\
\hline $\begin{array}{l}\text { Contribution } \\
\text { significance }\end{array}$ & 0.183 & $0.594^{* *}$ & $0.221^{*}$ & 0.076 & $0.206^{*}$ & ${ }^{*} 0.287^{* *}$ & $0.632^{* *}$ & $0.859^{* *}$ & $0.331^{* *}$ & 1.000 & \\
\hline $\begin{array}{l}\text { Empowerment } \\
\text { and employee } \\
\text { autonomy }\end{array}$ & $0.256^{*}$ & 0.196 & $0.326^{* *}$ & $0.310^{* *}$ & 0.142 & 0.156 & $0.406^{* *}$ & $0.449^{* *}$ & $0.256^{*}$ & $0.470^{* *}$ & 1.000 \\
\hline
\end{tabular}

\subsection{DISCUSSION}

\subsection{EXTRINSIC FACTORS INFLUENCE ON EMPLOYEE MOTIVATION}

The findings indicated that job enrichment, organizational information management and effective dissemination of information were the most important extrinsic factors that influenced employee motivation. The extrinsic factors are those factors affecting employee motivation which emanate from outside the task or the job. These findings agree with Chintaloo and Mahadeo (2013) who also identified that the work environment is an extrinsic factor affecting employee motivation. It further widens individual's scope of skills but some employees may not necessarily be satisfied because of an enriched job as argued by Whittaker (2008) which is contrary to this study's finding. Job enrichment makes individuals to have more responsibilities over their work, be more efficient and increase their performances. This is due to the fact that most employees feel that they have the autonomy to do what they are supposed to and the experience of self-confidence in their roles. Organizational information management and effective dissemination of information are other identified extrinsic factors. This is because whenever individuals accesses the organization's information without difficulties they feel like they are part of the organization and hence kills rumours, enhances trust, teamwork and contributes to decision making (Chiang and Jang, 2008).

Normally, employee performance depends on a large number of factors, such as motivation, appraisals, job satisfaction, training and development and many others (Chintaloo and Mahadeo 2013). Furthermore, the extrinsic factors are fundamental in influencing the employee to strive at achieving the set goals by efficiently performing the necessary tasks. According to Mudor and Tookson (2011), desire to achieve the set target is the motivation that makes most employees to perform efficiently and be good at something within the organization as the employee realizes that his or her efforts are worth much more to the organization. This is especially so with regard to the salary structure offered by the organization, the level of employee-management relationship as well as the quality of the work environment that the organization accords its employees (Chintaloo and Mahadeo 2013). According to the management guru 
Drucker (1974), there is no more powerful disincentive, no more effective hurdle to motivation than dissatisfaction over one's own pay compared to that of one's peers.

The findings also indicated that leadership style influenced employee motivation which agrees with Rukhmani et al., (2010) who also found out that leadership style influences people to do things in the right way. This may be attributed to the fact that the followers who are the employees would always want to do the right things which bring about high morale and motivation. Leadership is about influencing people to do things the right way. To achieve that an organization needs people to follow the leader and to have them trust in his or her leadership style.

\subsection{INTRINSIC FACTORS THAT INFLUENCE EMPLOYEE MOTIVATION}

Intrinsic motivation is the desire of an individual to perform his/her work well, in order to achieve the satisfaction of intrinsic needs. In other words, an individual performs a task in order to achieve certain types of internal states, which he/she experiences as intrinsic motivation relates to psychological rewards such as the recognition of a task completed (Annamalia et al., 2010),. The study identified appreciation of employees by the organization, the degree of skill requirement, influence of employee view of the job, employee perception on skill development, and the perception about contributing to the firms' growth were the most highly correlated intrinsic factors influencing employee motivation. Appreciation of employees by the organization among other recognitions influences employees' motivation and enhances employee job satisfaction and motivation. This is because when an employee is rewarded or recognized for the given activity done employees feel like they are part of the organization and will actually contribute to the organizational achievements.

The study also found out that the degree of skill variety requirement influences employee motivation. These findings are similar to Mathis and Jackson (2011) who also found out that the more the employee skills are involved the more meaningful the work becomes for the employee. Most employees would actually like to be recognized by their levels of skills and competencies within the organizations because they tend to feel relevant and the sense of belonging to the organization. This further enhances their attachment to the organization.

Influence of employee view of the job was another intrinsic factor which was identified to have influence on employee motivation. This is because most people work to earn a living in addition to other satisfactions that comes with the job such as doing something worthwhile. Some people work to earn a living to provide for their families meaning that those who benefit are outside the organization while others work to get satisfaction (Lunenburg and Ornstein, 2008). A worker who finds work meaningless may react apathetically even though all the environmental factors are well looked after. Employees are intrinsically motivated when they realize satisfaction, enjoyment from their jobs and have an opportunity to realize self-actualization.

The study identified employee perception on skill development was an intrinsic factor influencing employee motivation. This is because training provides chances for employee growth and enhances their knowledge and skills consequently their employability. The finding agrees with Abadi et al., (2011) found out that trained employees are more motivated with their jobs as opposed to the untrained employees. These findings also concur with Liebler and McConnell (2004) argument that training and development are the foundations of motivation and retention in any organization. There was a high correlation between trust and employee motivation because the employees feel they are valued in the organization. Trust is defined as the perception of one about others, decision to act based on communication, behaviour and their decision. If an organization wants to improve and be successful, trust plays a significant role so it should always be preserved to ensure an organizations existence and to enhance employees' motivation. It can make intrapersonal and interpersonal effects and influence on the relations inside and out the organization (Annamalia et al., 2010). 


\subsection{CONCLUSION}

Employee motivation is a highly sensitive concept which is affected by a multiplicity of factors. Some of these factors are extrinsic in that they emerge from within the organization and are an external obligation on the employee. In other words these factors are environmental most of which are within the controls of the organizational management and can as such be exploited by the management in order to boost the levels of employee motivation. The manner in which the organization handles or manages these extrinsic factors are indeed crucial in determining not only the level of employee motivation on their own but also do influence other factors, especially the intrinsic factors that further act as determinants of the level of motivation of employees.

The intrinsic factors are also important in determining employee satisfaction. This is probably because they are internal and go to the core of the employee's observation about their jobs and about how they feel that the tasks assigned to them are meaningful and relevant. The issue of motivation is individualistic or inherent in an employee and influence employee to develop a certain mind set regarding their jobs. Such perceptions control the level of employee motivation. It's important to know which factors motivate the employees in a given organization so that the management can put more emphasis on such factors. Human resource departments in organizations will be able to make informed decisions on what factors they should concentrate on in order to increase their employees' motivation.

Organizations should appreciate the effect of employee motivation in the long and short-term organizational goals and objectives. Further, organizations should acknowledge the effect of employee motivation on such organizational aspects as productivity and performance, employee absenteeism levels, employee turnover rates as well as employee stress levels. Therefore, the organization and the general management should consider implementing policies and practices that positively affect employee motivation. Such a strategy should be taken in tandem with the general organizational goals and objectives and should contribute to both the long-term and the short - term human resource strategy.

The empirical examination of extrinsic and intrinsic factors influencing motivation at AMREF Health Africa in Kenya raises a number of issues for future research. First, researchers should conduct a comparative study on the effect of employee motivation among public and private sector organizations to have a wider understanding of this intricate concept. Second, future research should study the impact of motivation on performance or productivity and control other factors so as to establish exactly the manner and extent to which the chosen factors do determine employee motivation consequently performance or productivity.

\section{REFERENCES}

Abadi, F. E., Jalilvand, M. R., Sharif, M., Salimi, G. A., \& Khanzadeh, S. A. (2011). A Study of Influential Factors on Employees' Motivation for Participating in the In-Service Training Courses Based on Modified Expectancy Theory. International Business and Management, 2 (1), 157-169.

Amrstrong, M. (2011) A Hand of Human Resource Management Practice (11 ${ }^{\text {th }}$ Edition). Kogan Page: London

Annamalai, T., Abdullah, A. G. K., \& Alasidiyeen, N. J., (2010).The Mediating Effects of Perceived Organizational Support on the Relationships between Organizational Justice, Trust and Performance Appraisal in Malaysian Secondary Schools. European Journal of Social Sciences, 13 (4), 623-632.

Cheng, L.L. (ed.) (1995), Integrating Language and Learning for Inclusion: An Asian Pacific Focus. San Diego and London: Singular Publishing.

Chiang, C.F., \& Jang, S.C. (2008). An expectancy theory model for hotel employee motivation. International Journal of Hospitality Management, 27: 313-322.

Chintaloo, J. \& Mahadeo D. (2013) Effect of Motivation on Employees' Work Performance at Ireland Blyth 
Limited. Proceedings of 8th Annual London Busin8ess Research Conference Imperial College, London, UK, 8 - 9 July ISBN: 978-1-922069-28-3

Daft R. L., (2009). Organization Theory and Design. Cengage Learning, Inc.

Drucker, P. (1974), Management, Tasks, Responsibilities, Practices. New York: Harper and Row Publishers.

Elliot, A., \& Zahn, I. (2008). Motivation. In: N. Salkind (Ed.), Encyclopedia of educational psychology. (pp. 687-693). Thousand Oaks, CA: SAGE Publications, Inc.

Fisher, D. M. (2012). Facet personality and surface-level diversity as team mental model antecedents: Implications for implicit coordination. Journal of Applied Psychology, 97(4), 825-841.

Gautam, M.; Mandal, K., \& Dalal, R.S. (2006). Job satisfaction of faculty members of veterinary sciences: an analysis. Livestock Research for Rural Development 18 (7).

Grant, A. M., Fried, Y., \& Juillerat, T. (2010). Work matters: Job design in classic and contemporary perspectives. Forthcoming in S. Zedeck (Ed.), APA handbook of industrial and organizational psychology. Washington, DC: American Psychological Association.

Guay, F (2010). Intrinsic, identified, and controlled types of motivation for school subjects in young elementary school children. British Journal of Educational Psychology, 8o(4), 711-735.

Gurland, S. T., \& Lam, C. F. (2008). Self-determined work motivation predicts job outcomes, but what predicts self-determined work motivation? Journal of world. (pp. 1161-1162). Thousand Oaks, CA: SAGE Publications, Inc.

Hays, W.L. (1988), Statistics, $4^{\text {th }}$ Edn. New York: Holt, Rinehart and Winston.

Herzberg, F. (1959) The motivation to work, New York: John

Hussin A. B. (2011). The relationship between job satisfaction and job satisfaction and job performance. Centre for graduate studies; Open university Malaysia.

Irons, J., \& Buskist, W. (2008). Operant Conditioning. In S. Davis, \& W. Buskist (Ed.), 21st Century psychology: a reference handbook. (pp. 1-329-1-340). Thousand Oaks, CA: SAGE Publications, Inc.

Karatepe, M.O. \& Uludag, O. (2007) Conflict, Exhaustion and Motivation: A Study of Frontline Employees in Northern Cyprus Hotels. Hospitality Management, Vol 26: 645-665.

Kamalian, A. R., Yaghoubi, N. M., \& Moloudi, J., (2010) Survey of Relationship between Organizational Justice and Empowerment (A Case Study). European Journal of Economics, Finance and Administrative Sciences, 24, 165-171.

Latham, G. P., \& Locke, E. A. (2007). New developments in and directions for goal- setting research. European Psychologist, 12(4), 290-300.

Liebler, J.G. and McConnell, C. R. (2004). Management Principles for Health Professionals ( $4^{\text {th }}$ Edition). Sudbury, MA: Jones and Bartlett Publishers, Inc.

Lunenburg, F. \& Ornstein, A. (2008). Educational administration: Concepts and practices. 5th Edition. Belmont CA: Thomson Wadsworth.

Mathis, R.L. \& Jackson, J.H. (2008). Human resource management. 12th Edition. Singerpore: Thomson Learning Academic.

Mudor, H. \& Tooksoon, P. (2011). "Conceptual Framework on the Relationship between Human Resource Management Practices, Job Satisfaction and Turnover", Journal of Economics \& Behavioural Studies. Vol. 2(2): pp. $41-49$.

Nyambegera, S.M.; Sparrow, P. \& Daniels, K. (2000), The Impact of Cultural Value Orientations on Individual HRM Preferences in Developing Countries: Lessons from Kenyan Organizations, International Journal of Human Resources Management, Vol. 11(4):639-663.

Ran, B. (2009). Motivation. In C. Wankel (Ed.), Encyclopedia of business in today's Research in Personality, 42(4), 1109-1115.

Rukhmani, K., Ramesh, M., \& Jayakrishnan, J., (2010). Effect of Leadership Styles on Organizational Effectiveness. European Journal of Social Sciences, 15 (3), 365-369.

Santrock, J. (2009). (4th ed.) Educational Psychology. New York, NY: McGrawhill

Sisk, D. (2009). Achievement motivation. In B. Kerr (Ed.), Encyclopedia of giftedness, creativity, and talent. (pp. 13-16). Thousand Oaks, CA: SAGE Publications, Inc.

Whittaker, C. (2008). Hotel operator motives in UK sale and leaseback/management-back transactions. International Journal of Hospitality Management, 27 (4): 641-648. 